\title{
Antibiotic-resistant Escherichia coli in deer and nearby water sources at Safari parks in Bangladesh
}

\author{
Md Samun Sarker ${ }^{1}$, Abdul Ahad ${ }^{1}$, Saurav Kumar Ghosh ${ }^{1}$, Md Shahriar Mannan², Arup Sen ${ }^{1}$, Sirazul Islam³, \\ Md Bayzid ${ }^{4}$ and Zamila Bueaza Bupasha ${ }^{1}$
}

1. Department of Microbiology and Veterinary Public Health, Faculty of Veterinary Medicine, Chattogram Veterinary and Animal Sciences University, Chattogram 4225, Bangladesh; 2. Department of Livestock Services, Upazila Livestock Office, Thakurgaon Sadar, Thakurgaon, Bangladesh; 3. Department of Livestock Services, Upazila Livestock Office, Mithamain, Kishoreganj, Bangladesh; 4. Department of Pathology and Parasitology, Faculty of Veterinary Medicine, Chattogram Veterinary and Animal Sciences University, Chattogram 4225, Bangladesh.

Corresponding author: Md. Samun Sarker, e-mail: samuncvasu@gmail.com

Co-authors: AA: abdul@cvasu.ac.bd, SKG: saurav55_cvasu@yahoo.com, MSM: shahriar.cvasu@gmail.com, AS: arup09dvm@gmail.com, SI: riponcvasu@gmail.com, MB: md.bayzid18fvm@gmail.com, ZBB: bupasha1494@gmail.com Received: 17-05-2019, Accepted: 03-09-2019, Published online: 19-10-2019

doi: 10.14202/vetworld.2019.1578-1583 How to cite this article: Sarker MS, Ahad A, Ghosh SK, Mannan MS, Sen A, Islam S, Bayzid M, Bupasha ZB (2019) Antibiotic-resistant Escherichia coli in deer and nearby water sources at Safari parks in Bangladesh, Veterinary World, 12(10): 1578-1583.

\begin{abstract}
Background and Aim: The emergence and rapid dissemination of multidrug-resistant (MDR) bacteria in different ecosystems is a growing concern to human health, animal health, and the environment in recent years. The study aimed to determine the antibiotic resistance in Escherichia coli from deer and nearby water sources at two different Safari parks in Bangladesh.

Materials and Methods: A number of 55 fresh fecal samples of deer and six water samples from nearby lakes were collected from two Safari parks. Samples were processed, cultured, and carried out biochemical tests for E. coli. The antibiotic susceptibility was determined by disk diffusion method. To identify the resistance genes, polymerase chain reaction was performed.

Results: A total of 32 E. coli isolates from 55 fecal samples and 6 of 6 E. coli isolates from lake water were isolated. From fecal $E$. coli isolates, ampicillin and sulfamethoxazole were $90.63 \%(n=29 / 32)$ resistant and $87.5 \%(n=28 / 32)$ were resistant to tetracycline and nalidixic acid. High resistance was also observed to other antibiotics. On the contrary, all E. coli isolates from water sources were $100 \%(n=6 / 6)$ resistant to ampicillin, tetracycline, sulfamethoxazole, and nalidixic acid. MDR was revealed in all water samples, whereas $96.88 \%(\mathrm{n}=31 / 32)$ was found in fecal isolates. A number of bla $a_{\mathrm{TEM}}$, tetA, and Sul2 genes were detected from both isolates.
\end{abstract}

Conclusion: This study for the $1^{\text {st }}$ time highlights, a significant proportion of $E$. coli isolates in wildlife deer and nearby water sources were MDR in Bangladesh.

Keywords: antibiotic-resistant, deer, Escherichia coli, lake, multidrug-resistant.

\section{Introduction}

Antibiotic resistance in wildlife is significant for human health due to the escalating of zoonotic diseases' importance and predicting the emergence and dissemination of resistant pathogens among different ecosystems [1]. As major reservoirs, the domestic animals are usually considered for antibiotic-resistant bacteria. In recent times, interest in resistant bacteria and corresponding resistant genes isolated from wildlife and the environment has increased. It is evident that resistant bacteria at different environmental compartments act as a vector and reservoirs due to widespread of multidrug-resistant (MDR) bacteria [2].

\footnotetext{
Copyright: Sarker, et al. Open Access. This article is distributed under the terms of the Creative Commons Attribution 4.0 International License (http://creativecommons.org/licenses/by/4.0/), which permits unrestricted use, distribution, and reproduction in any medium, provided you give appropriate credit to the original author(s) and the source, provide a link to the Creative Commons license, and indicate if changes were made. The Creative Commons Public Domain Dedication waiver (http://creativecommons.org/ publicdomain/zero/1.0/) applies to the data made available in this article, unless otherwise stated.
}

Escherichia coli, commensal bacteria of warm-blooded animals, is widely used as fecal contamination indicator [3]. The presence of pathogenic strains of $E$. coli in wild animals, such as deer, may comprise a risk for human and other animals' health [4]. The occurrence of antibiotic resistance in $E$. coli isolated from wild animals is not directly exposed to antibiotic treatment $[5,6]$. Through the attainment of resistant bacteria from human settings, agriculture, pharmaceuticals, hospitals, and associated tainted environments, they may be infected with antibiotic-resistant bacteria [7]. Even, in the pristine environments, where there was no direct human influence such as habitation, hospitals, and agricultural farming, resistant bacteria were reported $[8,9]$.

There are a large number of captive deer at two different Safari parks in Bangladesh. Antimicrobials are not administered except for severe injury or disease outbreak. The purpose of raised deer at Safari parks is to conserve and for recreation of visitors. Nearby of deer habitat in Safari parks have a number of lakes that are used as the main source of drinking 
water of deer, easily polluted by visitors, droppings of wild birds and farming. The occurrence of antibiotic-resistant $E$. coli in wildlife and their environments have been reported worldwide [10-13]. Antibioticresistant E. coli has been reported in Bengal tigers at Safari parks in Bangladesh [14]. However, to the best of our knowledge, no previous research has been focused on antibiotic-resistant in $E$. coli isolated from deer and surrounding environments in Bangladesh.

This study aimed to assess the antibiotic-resistant with some corresponding resistant genes of $E$. coli in deer and nearby aquatic sources at two different Safari parks in Bangladesh.

\section{Materials and Methods}

\section{Ethical approval}

Since samples were collected from the environment, ethical approval was not necessary for this study.

\section{Sample collection}

Environmental fresh fecal swab samples were collected aseptically from deer from two different Safari parks in Bangladesh, namely, Bangabandhu Sheikh Mujib Safari Park, Gazipur (latitude 23.71 and longitude 90.42, n=30) and Bangabandhu Sheikh Mujib Safari Park, Cox's Bazar (latitude 21.43 and longitude 92.01, $\mathrm{n}=25$ ), during the period of January-March 2016. It is interesting to note that the name of both Safari parks are same but they differ only in location. Immediately after collection, all samples were stored into a sterile screw-capped Falcon tube containing buffered peptone water (BPW). Along with feces, three water samples were also collected from each Safari park's lake during that time. In a sterile Falcon tube, $40 \mathrm{ml}$ of water sample was taken. Fecal and water samples were kept into an icebox and shipped in an unbroken freeze chain to the Poultry Research and Training Centre (PRTC), Chattogram Veterinary and Animal Sciences University (CVASU) as early as possible.

\section{$E$. coli isolation and identification}

Fecal sample in BPW (Oxoid, UK) was incubated overnight at $37^{\circ} \mathrm{C}$ for enrichment. One loop full of enriched broth was plated onto MacConkey agar (Oxoid, UK) from BPW, incubated for 18-24 h at $37^{\circ} \mathrm{C} .50 \mu \mathrm{l}$ of water sample was directly inoculated onto MacConkey agar and incubated overnight at $37^{\circ} \mathrm{C}$. On MacConkey agar, large pink-colored colonies were suspected as E. coli. A single isolated colony from MacConkey agar was subjected onto Eosin Methylene Blue (EMB; Merck, Mumbai) agar, characteristic green colonies with metallic sheen indicated as positive one. Different biochemical tests were conducted to confirm E. coli as earlier described by Gupta et al. [15]. Positive E. coli isolates were preserved in trypticase soy broth (TSB; Oxoid, UK) with $15 \%$ glycerol at $-80^{\circ} \mathrm{C}$ until use.

\section{Antibiotic susceptibility testing}

The disk diffusion method was performed on Mueller-Hinton agar (Oxoid, UK) plate to assess the antibiotic susceptibility of $E$. coli isolates according to the guidelines and recommendations of the Clinical and Laboratory Standards Institute (CLSI) [16]. The following 10 antibiotics that have both human and veterinary importance were tested: Ampicillin $(10 \mu \mathrm{g})$, tetracycline $(30 \mu \mathrm{g})$, ceftriaxone $(30 \mu \mathrm{g})$, erythromycin $(15 \mu \mathrm{g})$, chloramphenicol $(30 \mu \mathrm{g})$, sulfamethoxazole $(25 \mu \mathrm{g})$, nalidixic acid $(30 \mu \mathrm{g})$, ciprofloxacin $(5 \mu \mathrm{g})$, colistin $(10 \mu \mathrm{g})$, and gentamicin $(10 \mu \mathrm{g})$ (HiMedia, India). The susceptibility results were interpreted by the CLSI [16]. Isolate being resistant to at least three antimicrobial agents was defined as multidrug resistance [17].

\section{DNA extraction}

DNA was extracted by the boiling method [18] with slight modifications. In $1.5 \mathrm{ml}$ sterile Eppendorf tube, 2-3 fresh colonies were taken that contained $200 \mu 1$ of deionized water and vortexed thoroughly. The Eppendorf tube was heated at $99^{\circ} \mathrm{C}$ for $15 \mathrm{~min}$ and centrifuged at $15,000 \mathrm{rpm}$ for $2 \mathrm{~min}$. The collected supernatant was used as a DNA template and stored at $-20^{\circ} \mathrm{C}$ until use.

\section{Detection of antibiotic-resistant genes}

Polymerase chain reaction (PCR) was performed to detect the antibiotic-resistant genes in a final volume of $25 \mu \mathrm{l}$ consisting of $12.5 \mu \mathrm{l}$ dream Taq PCR Master Mix (Thermo Scientific, USA), $0.5 \mu l$ of each primer, $1 \mu \mathrm{l}$ template DNA, and $10.5 \mu \mathrm{l}$ deionized water. Previously published PCR conditions were used to determine the presence of bla ${ }_{\mathrm{TEM}}, t e t \mathrm{~A}, \operatorname{tet} \mathrm{B}, \operatorname{tet} \mathrm{C}$, and sul2 genes (Table-1) [19-22]. PCR was carried out using a thermocycler (2720 Thermal Cycler, Applied

Table-1: Primers used to identify antibiotic-resistant genes, bla $\mathrm{TEM}_{\mathrm{TE}}$ tetA, tetB, tetC, and su/2.

\begin{tabular}{|c|c|c|c|c|}
\hline $\begin{array}{l}\text { Target } \\
\text { gene }\end{array}$ & Primer sequence $\left(5^{\prime}-3^{\prime}\right)$ & Amplicon size (bp) & Annealing temperature $\left({ }^{\circ} \mathrm{C}\right)$ & References \\
\hline$b l a_{\mathrm{TEM}}$ & $\begin{array}{l}\text { F: TACGATACGGGAGGGCTTAC } \\
\text { R: TTCCTGTITGCTCACCCA }\end{array}$ & 716 & 53 & [19] \\
\hline tetA & $\begin{array}{l}\text { F: GCTACATCCTGCTTGCCTTC } \\
\text { R: CATAGATCGCCGTGAAGAGG }\end{array}$ & 210 & 55 & [20] \\
\hline tetB & $\begin{array}{l}\text { F: TTGGTTAGGGGCAAGTITG } \\
\text { R: GTAATGGGCCAATAACACCG }\end{array}$ & 659 & 55 & {$[21]$} \\
\hline tetC & $\begin{array}{l}\text { F: CTTGAGAGCCTTCAACCCAG } \\
\text { R: ATGGTCGTCATCTACCTGCC }\end{array}$ & 418 & 55 & {$[21]$} \\
\hline sul2 & $\begin{array}{l}\text { F: CGGCATCGTCAACATAACCT } \\
\text { R: TGTGCGGATGAAGTCAGCTC }\end{array}$ & 721 & 66 & {$[22]$} \\
\hline
\end{tabular}


Biosystems, USA). The amplified products of PCR were then visualized on $1.5 \%$ agarose gels stained with ethidium bromide $(0.5 \mu \mathrm{g} / \mathrm{ml})$ (Sigma-Aldrich, USA). A DNA ladder (100-bp, Thermo Fisher Scientific) was used to determine the size of PCR products. The gel was inspected visually and photographed using an ultraviolet transilluminator (BDA digital, Biometra $\mathrm{GmbH}$, Germany). As a positive control for a particular gene, previously isolated strain harboring of that gene was used from Microbiology Laboratory, CVASU.

\section{Statistical analysis}

Data were managed into a spreadsheet program (Excel 2010, Microsoft Corporation). The proportion of samples with $95 \%$ confidence interval and other descriptive statistics were calculated by QuickCalcs GraphPad software.

\section{Results}

Proportion and cultural characteristics of $E$. coli

A proportion of $60 \%(\mathrm{n}=18 / 30,95 \%$ CI 42.29 75.44) E. coli from deer feces and $100 \%(\mathrm{n}=3 / 3,95 \%$ CI 38.25-100) E. coli from water samples was isolated from Bangabandhu Sheikh Mujib Safari Park, Gazipur, whereas 56\% ( $\mathrm{n}=14 / 25$, 95\% CI 37.05$73.35)$ and $100 \%(\mathrm{n}=3 / 3,95 \%$ CI 38.25-100) E. coli found in deer feces and water samples, respectively, at Bangabandhu Sheikh Mujib Safari Park, Cox's Bazar. Overall, 58.18\% ( $\mathrm{n}=32 / 55$, 95\% CI 45.0270.27) E. coli from feces and $100 \%(\mathrm{n}=6 / 6,95 \% \mathrm{CI}$ 55.72-100) E. coli in water samples were isolated. Positive E. coli isolates produced bright pink colonies on MacConkey agar and characteristic green colonies with the metallic sheen on EMB agar. In methyl red and indole production test, all isolates were positive but negative to Voges-Proskauer test.

\section{Antibiotic resistance}

Of the 32 tested isolates of $E$. coli from feces, $90.63 \%(n=29 / 32)$ were resistant to ampicillin and sulfamethoxazole and $87.5 \%(\mathrm{n}=28 / 32)$ were resistant to tetracycline and nalidixic acid. Resistance to erythromycin and chloramphenicol was $56.25 \%(\mathrm{n}=18 / 32)$ and $53.13 \%(\mathrm{n}=17 / 32)$, respectively. Results also dictated $93.75 \%(\mathrm{n}=30 / 32)$ of $E$. coli isolates were sensitive to colistin followed by ceftriaxone $(81.25 \%$, $n=26 / 32)$ and gentamicin $(56.25 \%, n=18 / 32)$. On the contrary, all E. coli isolates were resistant to ampicillin, tetracycline, sulfamethoxazole, and nalidixic acid from water. None of the isolates were resistant to ceftriaxone and ciprofloxacin. Antibiotic susceptibility to different antibiotics is illustrated in Figure-1a and b. All of the E. coli isolates from deer unveiled that $96.88 \%(n=31 / 32)$ were MDR, whereas $100 \%(n=6 / 6)$ MDR were revealed in water samples. The common antibiotic-resistant patterns were ampicillin, tetracycline, sulfamethoxazole, and nalidixic acid for both feces and water isolates. There were 20 and four different MDR patterns were identified in fecal and water isolates, respectively (Table-2).

Table-2: Antibiotic-resistant patterns in Escherichia coli isolates from deer $(n=32)$ and water $(n=6)$.

\begin{tabular}{|c|c|c|}
\hline $\begin{array}{l}\text { Antibiotic-resistant } \\
\text { patterns }\end{array}$ & $\begin{array}{l}\text { Number of } \\
\text { isolates }\end{array}$ & Source \\
\hline AMP-TE & 1 & Feces \\
\hline AMP-E-C & 1 & Feces \\
\hline AMP-TE-SXT-NA & 4 & Feces \\
\hline TE-CRO-SXT-NA & 1 & Feces \\
\hline TE-E-C-CIP & 1 & Feces \\
\hline AMP-TE-SXT-NA-CN & 1 & Feces \\
\hline AMP-TET-E-C-SXT & 1 & Feces \\
\hline AMP-TE-E-SXT-NA & 4 & Feces \\
\hline AMP-E-SXT-NA-CN & 1 & Feces \\
\hline AMP-TE-C-SXT-NA & 1 & Feces \\
\hline AMP-E-SXT-NA-CIP & 1 & Feces \\
\hline AMP-TE-E-C-SXT-NA & 4 & Feces \\
\hline AMP-TE-CRO-E-SXT-NA & 1 & Feces \\
\hline AMP-TE-C-SXT-NA-CN & 2 & Feces \\
\hline TE-CRO-E-C-SXT-NA & 1 & Feces \\
\hline AMP-C-SXT-NA-CIP-CN & 1 & Feces \\
\hline AMP-TE-C-SXT-NA-CIP & 2 & Feces \\
\hline AMP-TE-E-C-SXT-NA-CIP & 2 & Feces \\
\hline AMP-TE-CRO-C-SXT-NA-CN & 1 & Feces \\
\hline AMP-TE-CRO-E-SXT-NA-CIP & 1 & Feces \\
\hline AMP-TE-SXT-NA & 1 & Water \\
\hline AMP-TE-SXT-NA-CN & 1 & Water \\
\hline AMP-TE-SXT-NA-CT & 2 & Water \\
\hline AMP-TE-E-C-SXT-NA & 2 & Water \\
\hline
\end{tabular}

$\mathrm{AMP}=$ Ampicillin, $\mathrm{TE}=$ Tetracycline, $\mathrm{CRO}=$ Ceftriaxone, $\mathrm{E}=$ Erythromycin, $\mathrm{C}=$ Chloramphenicol, SXT =Sulfamethoxazole, NA=Nalidixic acid $\mathrm{CIP}=$ Ciprofloxacin, $\mathrm{CT}=$ Colistin, $\mathrm{CN}=$ Gentamicin
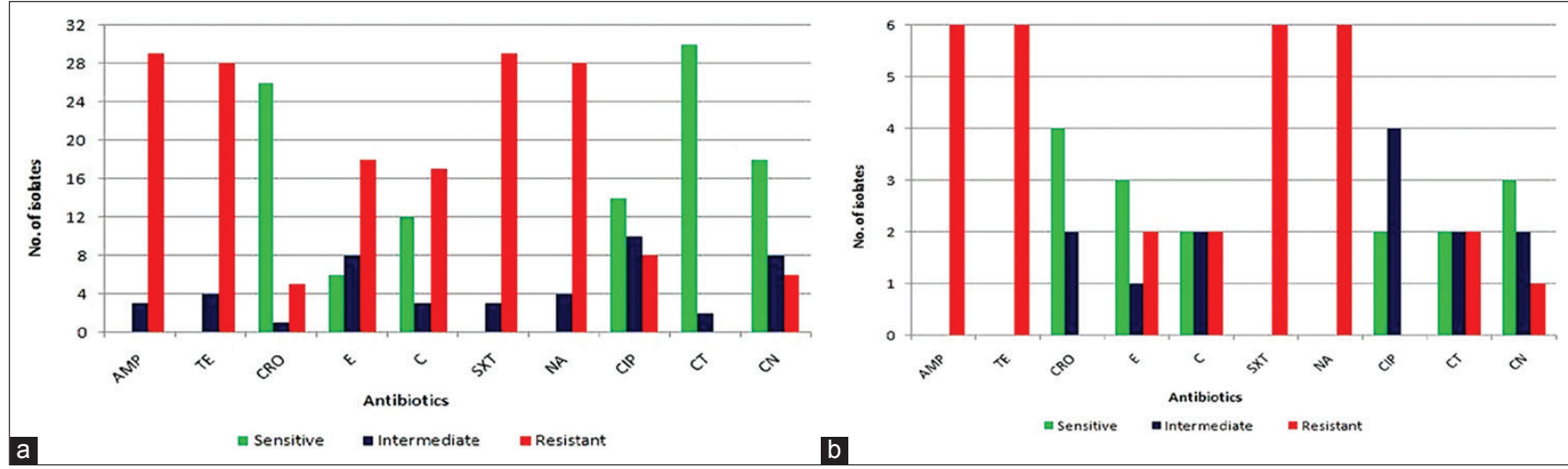

Figure-1: (a) Antibiogram profile of deer Escherichia coli isolates against different antibiotics (b) Antibiogram profile of water $E$. coli isolates against different antibiotics. 


\section{Antibiotic-resistant genes}

We have characterized some of the targeting antibiotic-resistant genes on a molecular basis, namely, bla ${ }_{\text {ТЕм }}$ ( $\beta$-lactamase resistant gene), tet $\mathrm{A}$, tet $\mathrm{B}$, tet $\mathrm{C}$ (tetracycline-resistant gene), and sul2 (sulfur drug-resistant gene). In case of feces, of 29 ampicillin and sulfamethoxazole resistant isolates, $58.62 \%(\mathrm{n}=17 / 29)$ and $34.48 \%(\mathrm{n}=10 / 29)$ exposed $b l a_{\mathrm{TEM}}$ and sul2 genes, respectively. Eleven (39.29\%) of the 28 tetracycline-resistant isolates contained the tet $\mathrm{A}$ gene. On the contrary, $66.67 \%(\mathrm{n}=4 / 6)$ of water isolates contained $b l a_{\text {TEM }}$ gene, whereas $33.33 \%$ $(\mathrm{n}=2 / 6)$ of isolates carried both tetA and sul2 gene. tet $\mathrm{B}$ and tet $\mathrm{C}$ gene were not exposed in any of the tested isolates from both sources.

\section{Discussion}

In the present study, the overall proportion of fecal carriage E. coli from deer at two different Safari parks was $58.18 \%$. Based on exhaustive literature searches, there are no available reports that predate our detection of E. coli in deer at Safari parks in Bangladesh. A similar study reported by Alonso et al. [23] who found 59\% of E. coli from wild deer, whereas Carroll et al. [24] isolated $83 \%$ of $E$. coli. These variations may be due to the sample size, contamination of fecal samples with the surrounding environment, and geographical distribution.

Deer $E$. coli isolates were subjected to 10 antimicrobial agents to assess the antibiotic susceptibility pattern. E. coli isolates were resistant to at least two antibiotics, most commonly practiced in human and veterinary medicine in Bangladesh. In our study, the common phenotypic-resistant patterns were ampicillin, tetracycline, sulfamethoxazole, and nalidixic acid. We found that $90.63 \%(n=29 / 32)$ of resistance to ampicillin and sulfamethoxazole and $87.5 \%(n=28 / 32)$ of resistance to tetracycline and nalidixic acid. Higher resistance was also observed against erythromycin and chloramphenicol at $56.25 \%$ $(n=18 / 32)$ and $53.13 \%(n=17 / 32)$, respectively. This resistance profile is higher than $\mathrm{Li}$ et al. [25] who reported that ampicillin, sulfamethazine, and tetracycline were $71.4 \%, 82.7 \%$, and $80 \%$ resistant, respectively, in Northeastern China. However, 93.75\% $(\mathrm{n}=30 / 32)$ of $E$. coli isolates were sensitive to colistin followed by ceftriaxone $(81.25 \%)$ and gentamicin $(56.25 \%)$. Resembling to our study, antibiotic-resistant $E$. coli were found in the environmental and biological sources such as human urine, human feces, sheep, goat, cattle, chicken, pigeon, broiler, duck, soil, and drain sewage in Bangladesh [26,27]. The results we have observed are a matter of great concern as to how these deer acquired resistance, though they were treated very rarely with these human-associated antibiotics at Safari parks. This may be due to deforestation and spillage of organism from human dwellings and wildlife in both directions.

From the nearby lakes, water samples were collected as lake water is supplied to deer as their drinking water. E. coli was isolated from all water samples, demonstrated the same resistance pattern as like deer isolates. About $100 \%$ of water isolates were resistant to ampicillin, tetracycline, sulfamethoxazole, and nalidixic acid. The studied area is in the main route of bird migration in Bangladesh and lake hosts thousands of wild birds. The wild birds can act as vectors and reservoirs of antibiotic-resistant bacteria that have veterinary and medical importance [28]. Wild birds pick up food from various environments and human surroundings are heavily polluted by resistant bacteria in Bangladesh [29] and lead to polluting natural water reservoirs such as lakes and rivers by inducing fecal contaminates [30] and dissemination of resistant bacteria. We have speculated that antibiotic resistance might have been transferred to deer through E. coli contaminated water. Moreover, in Bangladesh, animal manure is commonly used in agricultural application, which is a significant pathway into the terrestrial environment for the introduction of resistant bacteria. As a result, deer may acquire resistant bacteria during their grazing on pastureland.

Our study revealed that $96.88 \%$ of deer E. coli isolates were MDR, whereas $100 \%$ MDR was found in water isolates. Due to the indiscriminate victimization of antimicrobial agents, MDR strains may apparently occur with high incidence [31]. However, the findings of the MDR patterns of this study will help for the choice of drugs for the veterinarians to practice at Safari parks.

A number of different resistant genes, namely, $b l a_{\mathrm{TEM}}$, tet $\mathrm{A}$, and sul2 were detected in both fecal and water $E$. coli in the present study. To the best of author's knowledge, there are no previous reports on antibiotic-resistant with associated genes in E. coli from deer population at Safari parks in Bangladesh. The findings were in line with the data obtained from other countries by Alonso et al. [23] and Li et al. [25] who reported bla ${ }_{\text {TEM, }}$, tetA, and sul2 genes in E. coli isolates in wild deer. The spreading of resistance genes in natural environment may be a great threat to human and animal health.

\section{Conclusion}

The study dictated the presence of MDR and some of their corresponding resistant genes in deer and nearby aquatic sources at Safari parks in Bangladesh. Nationwide effective antimicrobial resistance surveillance is badly needed to monitor the antimicrobials use and understanding the role of antimicrobial-resistant bacteria in the domestic and wild environments to diminish the public health challenge.

\section{Authors' Contributions}

MSS and AA conceived and designed the study. MSS and SKG collected samples from Safari parks. MSS, ZBB, and MB performed laboratory experiments. AS and MSM analyzed the data. MSS wrote the manuscript. AA and SI critically reviewed the manuscript. All the authors read and approved the manuscript for publication. 


\section{Acknowledgments}

The authors thankfully acknowledge help from the Bangladesh Forest Department and staff of both Safari parks. The authors also acknowledge help and support of the staff of the Department of Microbiology and Veterinary Public Health and PRTC, Chattogram Veterinary and Animal Sciences University (CVASU). As part of an M.Sc. study, this research is funded by the Department of Microbiology and Veterinary Public Health, CVASU, Bangladesh, grant No. MSS/0115/07/245/CVASU.

\section{Competing Interests}

The authors declare that they have no competing interests.

\section{Publisher's Note}

Veterinary World remains neutral with regard to jurisdictional claims in published institutional affiliation.

\section{References}

1. Radhouani, H., Silva, N., Poeta, P., Torres, C., Correia, S. and Igrejas, G. (2014) Potential impact of antimicrobial resistance in wildlife, environment and human health. Front. Microbiol., 5(2): 23.

2. Martinez, J.L. (2008) Antibiotics and antibiotic resistance genes in natural environments. Science, 321(5887): 365-367.

3. Schets, F.M., van Wijnen, J.H., Schijven, J.F., Schoon, H. and de Roda Husman, A.M. (2008) Monitoring of waterborne pathogens in surface waters in Amsterdam, the Netherlands, and the potential health risk associated with exposure to Cryptosporidium and giardia in these waters. Appl. Environ. Microbiol., 74(7): 2069-2078.

4. Carrillo-Del Valle, M.D., De la Garza-Garcia, J.A., Diaz-Aparicio, E., Valdivia-Flores, A.G., CisnerosGuzman, L.F., Rosario, C., Manjarrez-Hernandez, A.H., Navarro, A., Xicohtencatl-Cortes, J., Maravilla, P. and Hernandez-Castro, R. (2016) Characterization of Escherichia coli strains from red deer (Cervus elaphus) faeces in a Mexican protected natural area. Eur. J. Wildl. Res., 62(4): 415-421.

5. Radimersky, T., Frolkova, P., Janoszowska, D., Dolejska, M., Svec, P., Roubalova, E., Cikova, P., Cizek, A. and Literak, I. (2010) Antibiotic resistance in faecal bacteria (Escherichia coli, Enterococcus spp.) in feral pigeons. $J$. Appl. Microbiol., 109(5): 1687-1695.

6. Vittecoq, M., Godreuil, S., Prugnolle, F., Durand, P., Brazier, L., Renaud, N., Arnal, A., Aberkane, S., Jean-Pierre, H., Gauthier-Clerc, M., Thomas, F. and Renaud, F. (2016) Antimicrobial resistance in wildlife. $J$. Appl. Ecol., 53(2): 519-529.

7. Dolejska, M., Cizek, A. and Literak, I. (2007) High prevalence of antimicrobial-resistant genes and integrons in Escherichia coli isolates from black-headed gulls in the Czech Republic. J. Appl. Microbiol., 103(1): 11-19.

8. Hernandez, J., Stedt, J., Bonnedahl, J., Molin, Y., Drobni, M., Calisto-Ulloa, N., Gomez-Fuentes, C., AstorgaEspana, M.S., González-Acuna, D., Waldenstrom, J., Blomqvist, M. and Olsen, B. (2012) Human-associated extended-spectrum beta-lactamase in the Antarctic. Appl. Environ. Microbiol., 78(6): 2056-2058.

9. Sjolund, M., Bonnedahl, J., Hernandez, J., Bengtsson, S., Cederbrant, G., Pinhassi, J., Kahlmeter, G. and Olsen, B. (2008) Dissemination of multidrug-resistant bacteria into the Arctic. Emerg. Infect. Dis., 14(1): 70-72.

10. Marinho, C., Silva, N., Pombo, S., Santos, T., Monteiro, R.,
Goncalves, A., Micael, J., Rodrigues, P., Costa, A.C., Igrejas, G. and Poeta, P. (2013) Echinoderms from Azores Islands: An unexpected source of antibiotic resistant Enterococcus spp. and Escherichia coli isolates. Mar. Pollut. Bull., 69(1-2): 122-127.

11. Navarro-Gonzalez, N., Casas-Diaz, E., Porrero, C.M., Mateos, A., Dominguez, L., Lavin, S. and Serrano, E. (2013) Food-borne zoonotic pathogens and antimicrobial resistance of indicator bacteria in urban wild boars in Barcelona, Spain. Vet. Microbiol., 167(3-4): 686-689.

12. Pesapane, R., Ponder, M. and Alexander, K.A. (2013) Tracking pathogen transmission at the human-wildlife interface: Banded mongoose and Escherichia coli. Ecohealth., 10(2): 115-128.

13. Santos, T., Silva, N., Igrejas, G., Rodrigues, P., Micael, J., Rodrigues, T., Resendes, R., Goncalves, A., Marinho, C., Goncalves, D., Cunha, R. and Poeta, P. (2013) Dissemination of antibiotic-resistant Enterococcus spp. and Escherichia coli from wild birds of Azores Archipelago. Anaerobe, 24(6): 25-31

14. Ghosh, S.K., Bupasha, Z.B., Nine, H.S.M., Sen, A., Ahad, A. and Sarker, M.S. (2019) Antibiotic resistance of Escherichia coli isolated from captive Bengal tigers at Safari parks in Bangladesh. J. Adv. Vet. Anim. Res., 6(3): 341-345.

15. Gupta, M.D., Islam, M., Sen, A., Sarker, M.S. and Das, A. (2017) Prevalence and antibiotic susceptibility pattern of Escherichia coli in cattle on Bathan and intensive rearing system. Microbes Health, 6(1): 1-4.

16. Clinical and Laboratory Standards Institute. (2012) Performance Standards for Antimicrobial Disk Susceptibility Tests; Approved Standard. $11^{\text {th }}$ ed. Document M02-A11. Clinical and Laboratory Standards Institute, Wayne, PA

17. Begum, R., Sarker, M.S., Ngamsanga, P., Pulsrikarn, C., Pichpol, D., Meeyam, T. and Chaisowwong, W. (2018) Prevalence and Antimicrobial Resistance of Salmonella Isolated from Meat and Eggs in Muang District in Chiang Mai Province, Thailand. The $5^{\text {th }}$ Food Safety and Zoonoses Symposium for Asia Pacific, Chiang Mai, Thailand (6-7 July). p73-79.

18. Sánchez, S., Martínez, R., García, A., Benítez, J., Blanco, J., Blanco, J., Blanco, M., Dahbi, G., López, C. and Mora, A. (2010) Variation in the prevalence of non-O157 Shiga toxin-producing Escherichia coli in four sheep flocks during a 12-month longitudinal study. Small Rumin. Res., 93(2-3): 144-148.

19. Belaaouaj, A., Lapoumeroulie, C., Canica, M.M., Vedel, G., Nevot, P., Krishnamoorthy, R. and Paul, G. (1994) Nucleotide sequences of the genes coding for TEM-like beta-lactamases IRT-1 and IRT-2 (formerly called TRI-1 and TRI-2). FEMS Microbial. Lett., 120(1-2): 75-80.

20. Karczmarczyk, M., Abbott, Y., Walsh, C., Leonard, N. and Fanning, S. (2011) Characterization of multidrug-resistant Escherichia coli isolates from animals presenting at a university veterinary hospital. Appl. Environ. Microbiol., 77(20): 7104-7112.

21. Ng, L.K., Martin, I., Alfa, M. and Mulvey, M. (2001) Multiplex PCR for the detection of tetracycline-resistant genes. Mol. Cell. Probes, 15(4): 209-215.

22. Lanz, R., Kuhnert, P. and Boerlin, P. (2003) Antimicrobial resistance and resistance gene determinants in clinical Escherichia coli from different animal species in Switzerland. Vet. Microbiol., 91(1): 73-84.

23. Alonso, C.A., González-Barrio, D., Tenorio, C., Ruiz-Fons, F. and Torres, C. (2016) Antimicrobial resistance in faecal Escherichia coli isolates from farmed red deer and wild small mammals. Detection of a multiresistant $E$. coli producing extended-spectrum beta-lactamase. Comp. Immunol. Microbiol. Infect. Dis., 45(2): 34-39.

24. Carroll, D., Wang, J., Fanning, S. and McMahon, B.J. (2015) Antimicrobial resistance in wildlife: Implications for public health. Zoonoses Public Health, 62(7): 534-542. 
25. Li, R., He, L., Hao, L., Wang, Q., Zhou, Y. and Jiang, H. (2013) Genotypic and phenotypic characterization of antimicrobial-resistant Escherichia coli from farm-raised diarrheic sika deer in Northeastern China. PLoS One, 8(9): e73342.

26. Zinnah, M.A., Haque, M.H., Islam, M.T., Hossain, M.T., Bari, M.R., Babu, S.A.M., Rahman, M.T. and Islam, M.A. (2008) Drug sensitivity pattern of Escherichia coli isolated from samples of different biological and environmental sources. Bangladesh J. Vet. Med., 6(1): 13-18.

27. Sarker, M.S., Mannan, M.S., Ali, M.Y., Bayzid, M., Ahad, A. and Bupasha, Z.B. (2019) Antibiotic resistance of Escherichia coli isolated from broilers sold at live bird markets in Chattogram, Bangladesh. J. Adv. Vet. Anim. Res., 6(3): 272-277.

28. Radhouani, H., Poeta, P., Goncalves, A., Pacheco, R., Sargo, R. and Igrejas, G. (2012) Wild birds as biological indicators of environmental pollution: Antimicrobial resistance patterns of Escherichia coli and enterococci isolated from common buzzards (Buteo buteo). J. Med. Microbiol., 61(6): 837-843.

29. Hasan, B., Melhus, A., Sandegren, L., Alam, M. and Olsen, B. (2014) The gull (Chroicocephalus brunnicephalus) as an environmental bioindicator and reservoir for antibiotic resistance on the coastlines of the Bay of Bengal. Microb. Drug. Resist., 20(5): 466-471.

30. Hubalek, Z. (2004) An annotated checklist of pathogenic microorganisms associated with migratory birds. J. Wildl. Dis., 40(4): 639-659.

31. van den Boogard, A.E. and Stobberingh, E.E. (2000) Epidemiology of resistance to antibiotics. Links between animals and humans. Int. J. Antimicrob. Agents, 14(4): 327-335.

$* * * * * * * *$ 